ISPEC Tarım Bilimleri Dergisi

$2020: 4(4)$

(C) Telif hakk ISPEC'e aittir

Arasturma Makalesi

\section{*Gülşah BENGÍSU}

Orcid No: 0000-0003-1214-0011

**Büşra ÇEKILMEZ

Orcid No: 0000-0002-6433-0135

*Harran Üniversitesi Ziraat Fakültesi

Tarla Bitkileri Bölümü (Sorumlu yazar)

**Harran Üniversitesi Tarla Bitkileri

Bölümü

gbengisu@hotmail.com

DOI

https://doi.org/10.46291/ISPECJASv ol4iss4pp900-920

Geliş Tarihi: $22 / 10 / 2020$

Kabul Tarihi: 20/11/2020

\footnotetext{
Anahtar Kelimeler

Harran, yem bitkileri, destekleme, teşvik
}

\section{Keywords}

Harran, foragecrops, supporting, incentive

\section{www.ispecjournal.com}

\section{Harran Ovası'nda Yem Bitkileri Tarımında Üretici \\ Davranışlarının Belirlenmesi}

\section{Özet}

$\mathrm{Bu}$ araştırma; Şanlıurfa iline bağlı Harran ilçesinde bulunan Altılı, Belitaş, Bulgurlu, Balkat, Aşağı Yakın Yol, Su Geldi köylerindeki ve Tarım İlçe Müdürlüğü 'ndeki üreticilerin yem bitkileri üretimine olan yaklaşımını ve 2018 yılında hayata geçirilen "Yem Bitkisi Üretimini Geliştirme Projesi" ne yönelik düşüncelerini belirlemek amacıyla yapılmıştır. Bu amaca yönelik anket soruları hazırlanmış, tesadüfen seçilen 6 köyde ve Harran Tarım ilçe müdürlüğünde bulunan toplamda 60 üretici ile yüz yüze görüşülerek anket yapılmış, anket sonuçları düzenlenmiş, elde edilen sonuçlar değerlendirilmiş ve yorumlanmıştır. Araştırma sonucunda üreticilere göre yem bitkisi tarımının gelişmemiş olmasının nedenleri arasında; yem bitkilerine uygulanan politikaların yetersiz olması, teşvik ve desteklemelerin uygulanışındaki eksiklikler, girdi maliyetlerinin yüksekliği ve verim düşüklüğü sayılabilir.

\section{Determination of Forage Crops Producer Behavior In Agriculture In Harran Plain}

\section{Abstract}

This investigation; in order to determine the approach of the producers in the villages of Altı, Belitaş, Bulgurlu, Balkat, Aşağı Close Road, Su Geldi and Agriculture District Directorate in Harran district of Şanliurfa province to the production of forage plants and their thoughts on the "Feed Plant Production Development Project" implemented in 2018. has been made Survey questions were prepared for this purpose, a total of 60 producers in 6 villages selected by chance and Harran Tarım district directorate were interviewed face to face, the survey results were prepared, the results obtained were evaluated and interpreted. According to the producers as a result of the research, among the reasons why the forage crop farming is not developed; Inadequate policies applied to forage crops, insufficient implementation of incentives and supports, high input costs and low yield can be listed. 


\section{GíRIŞ}

\section{Yem Bitkileri}

Yem bitkileri tarımı, sürekli ve güvenli kaba yem üretiminin en önemli yoludur (Akman ve ark. 2007). Tarımsal faaliyetler içerisinde çok önemli bir yere sahip olan yem bitkileri tarımı, bitkisel ve hayvansal üretimin destekleyicisi konumundadır. Tarım arazilerinde üretilen otlar öncelikle hayvanlar tarafindan kullanılmakta et, süt vb. ürünlere dönüştürülerek bu ürünlerden de insanlar yararlanmaktadır (Soya ve ark. 2004). Yem bitkileri, ucuz bir kaynak olması, hayvanların mide mikro florası için gerekli besin maddelerini içermesi, mineral ve vitaminlerce zengin olmas1, hayvanların üreme gücünü artırması ve yüksek kalitede hayvansal ürün sağlaması bakımından hayvan beslemede önemlidir (Serin ve Tan 2001). Yem bitkileri tarımı, çayır ve meraların üzerindeki aşırı otlatma baskısını hafifletecek, tahıl-nadas sistemlerinde münavebeye girerek nadas alanlarının daralmasına neden olacak ve sonuçta ülkemizdeki erozyon miktarını da azaltacaktır. Yem bitkisi yetiştiriciliğinin artması ile bozulan çayır ve mera vejetasyonları kendilerini yenileme firsatını yakalamış olacaklardır. Bunun yanında yem bitkileri ekim nöbetine girerek kendisinden sonraki ürünlere önemli katk1lar sağlamaktadır. Yem bitkilerinin ekim nöbetindeki etkinliklerini ve önemini maddeler halinde aşağıdaki şekilde özetlenebilir. (Soya ve ark. 2004).

1. Toprağın fiziksel ve kimyasal yapısını düzeltirler,

2. Toprağı organik maddece zenginleştirirler,

3. Yağış rejimine uymayı kolaylaştırırlar,

4. Doğayı korurlar, toprağın su ve rüzgar ile taşınmasını önlerler,

5. Topraktan üst düzeyde verim alınmasına olanak tanırlar,

6. Drenaja yardımcı olurlar,

7. Ekonomik ve doğal koşullardan oluşabilecek zararları önlerler,

8. Zararlılarla savaşta ve toprak yorgunluğunu gidermede önemli etkinlikler yaratabilirler,

9. İşletmelerde iş gücünün yıl içerisinde dağılımına yardımcı olurlar,

10. Evcil ve yabani hayvanlar için çok değerli yem kaynağıdırlar.

Ülkemizde uzun yıllardan beri süregelen kaba yem yetersizliği sorunu mevcuttur. Ülkemizde olduğu gibi Şanlıurfa koşullarında da mevcut hayvan varlığının beslenebilmesi için ihtiyaç duyulan kaba yem üretimi yeterli değildir. Kaba yem açığının kapatılmasında, tarla tarımı içerisinde alternatif yem bitkilerinin üretimine mutlaka yer verilmelidir. Tarım ve Orman Bakanlığı tarafından 2018 yılında 
hayata geçirilen proje ile 3 yıl üst üste tarım arazisine aynı ürünü eken çiftçinin desteklemeden yararlanamaması söz konusudur. Bu projede hem ürün çeşitliliği hem de çiftçilerin yeni ara ürünleri topraklarıyla buluşturarak verimliği artırılması hedeflenmiştir. $\mathrm{Bu}$ kapsamda çiftçiler, ülkemiz üretiminin yarısının Şanlıurfa'da yapıldığı pamuk hasadı sonrası ara ürüne yönelmiştir. Çiftçi, hasat sonrası 5 ay gibi bir süre boş kalan arazilerine ilk y1l devletten aldığı tohum desteği ile yem bitkisi ekmiştir. 2018 yılında hayata geçirilen bu proje ile bir yılda verimin yüzde $75^{\prime}$ 'in üzerinde artış gösterdiği çiftçiler tarafından gözlenmiştir.

\section{MATERYAL ve YÖNTEM}

\section{Materyal}

$\mathrm{Bu}$ araştırmanın ana materyalini Şanlıurfa'nın Harran Ovası'nda bulunan çiftçiler ile sahada yapılan anketlerden elde edilen veriler oluşturmaktadır. Ayrıca bu çalışmada hem birincil ve hem de ikincil veriler kullanılmıştır. Birincil veriler anketler yoluyla sahada çiftçiler ile yapılan yüz yüze görüşmelerden elde edilmiştir. Saha çalışması ve anketler 2020 yılında yapılmıştır. T. C. Gıda Tarım ve Hayvancılık Bakanlığı kararı üzerine "3 yıl üst üste tarım arazisine aynı ürünü eken çiftçi, destekleme alamayacak” zorunluluğu kapsamında çiftçiler, Türkiye'de üretiminin yarısının Şanlıurfa'da yapıldığı pamuk hasadı sonrası ara ürüne yönelmiştir. Harran Ovası'nın tamamına yakın bölümünde bu zorunluluğun uygulanması nedeniyle bu bölge araştırma alanı olarak seçilmiştir. Sahada tesadüfen seçilmiş köyde ve Harran Tarım İlçe Müdürlüğü'nde toplamda 70 kişi ile anket yapılmış olup, eksik, hatalı ve yanlış olanlar tespit edildikten sonra, 60 anket analizlerde kullanılmıştır. $\mathrm{Bu}$ sorulardaki esas amaç çiftçilerin yem bitkilerine ve yetiştiriciliğine olan bakış açıları ile yem bitkileri için uygulanan tarım politikaları hakkında ki düşüncelerini belirlemektir. Anketlerden elde edilen veriler belirli bir kod planına bağlı olarak, Excel'e işlenmiştir. Bu veriler, çalışmanın birincil ve ana materyalini oluşturmuştur. İkincil veriler ise, bu konularda yapılan önceki çalışmalardan, araştırmalardan, yayınlardan, kamu kurum ve kuruluşlarının yayınlamış olduğu bilgilerden elde edilmiştir. Daha sonra elde edilen birincil veriler ile ikincil verilere bağl1 değerlendirmeler yapılmış ve sonuçlar ile öneriler ortaya konmuştur.

\section{Yöntem}

Araştırma Şanlıurfa ili Harran Ovası'nda yürütülmüştür. Likert tipi sorulara yer verilmiş olup, bu Rensis Likert tarafından 
geliştirilen bir tutum ölçeğidir. İkili, üçlü, beşli, yedili ve dokuzlu kullanımları olmakla beraber, genel olarak kullanılan ölçek üçlüdür. Bu çalışmada üçlü ölçek kullanılmıştır ki, burada "katılıyorum"dan “katılmiyorum"a kadar uzanan bir yöntemdir. Likert ölçeğinde temel yaklaşım kişilere araştırılan konuyla ilgili faktörlerin verilmesi ve bu faktörler üzerinde yoğunlaşmanın bulunması esas alınmıştır. Faktör cümleleri tek anlamlı ve kesin sonuçludur. Çalışmanın sonunda her bir faktör cümlesine grubu oluşturan katılımcıların (burada çiftçiler) katılma derecelerinin sayısal dağılımı saptanır ve katılma seçeneklerinin sayısal değeri ile seçenek katsayısı çarpılarak elde edilen son değere göre sayısal ortalama hesaplanır. $\mathrm{Bu}$ ortalama değerler grubun seçenek değeri olarak alınır ve bulunan seçenek değeri ile karş1laştırılıp, faktörün tutum üzerindeki etkisi belirlenir. Likert ölçeklerinde güvenilirlik yüksek olup, genel olarak 0.85 güvenilirlik katsayısı kabul görür. Hazırlanan anketlerde çiftçilerin sosyoekonomik, sosyo-demografik, tarımsal faaliyetlerini ve düşüncelerini belirlemeye yönelik sorular sorulmuş ve elde edilen veriler belirli bir kod planına dayalı olarak Excel'e işlenmiştir.

\section{BULGULARI ve TARTIŞMA}

Çiftçilerin bazı sosyo-demografik

\section{özellikleri}

Ankete katılan çiftçilerin sosyoekonomik yapılarına ilişkin dağılımlar aşağıda verilmiştir. Katılımcıların yaş dağglımları Şekil 1'de izlenebilmektedir.

\section{ÇiFTÇiLERIN YAŞ ARALIKLARI}

\section{—33-45 yaş aralığındaki çiftçiler \\ 46-55 yaş aralığındaki çiftçiler \\ [ 56-70 yaş aralığındaki çiftçiler}

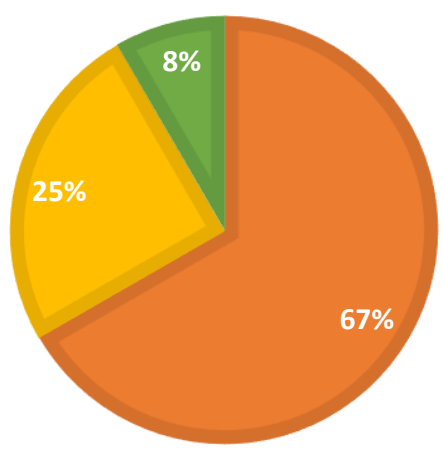

Şekil 1. Katılımcıların yaşlarına göre dağılımı 
Araştırma bölgesinde çiftçilerin \%8'inin $56-70, \% 25^{\prime}$ inin $46-55, \% 67$ 'sinin ise $33-45$ yaş grubunda olduğu gözlemlenmiştir. $\mathrm{Bu}$ anlamda görüşülen çiftçiler içerisinde küçük yaş grubunun olmaması okul veya askerliğe bağlanabilir. Eğitim insan yaşamında olağanüstü değişiklik yapan ve insanın içinde doğup büyüdüğü, yaşadığı toplumun değerlerini öğrenmeye ve kendisinden sonraki kuşaklara aktarmaya yönelten bir süreçtir (Erden 1994). Eğitim düzeyi, toplumların sosyal ve ekonomik gelişmesinde önemli bir gösterge olarak kabul edilmektedir. Bu nedenle çiftçilerin eğitim düzeylerinin belirlenmesi amacıyla soru sorulmuş ve toplanan verilerle Şekil 2'de düzenlenmiştir.

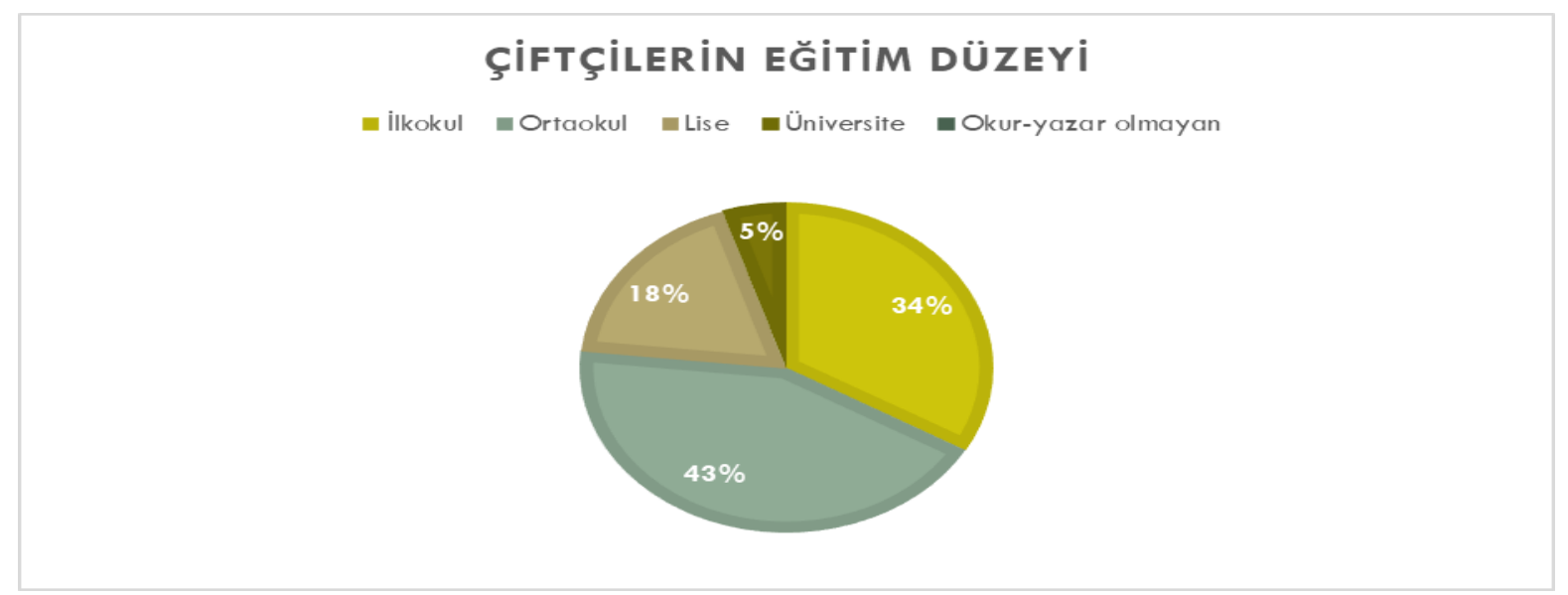

Şekil 2. Çiftçilerin eğitim düzeyleri

Yapılan araştırmalara göre çiftçilerin \% \%'i üniversite, \%18'i lise, \%34'ü ilkokul, \%43'ü ise ortaokul olarak belirlenmiştir.

Bununla beraber görüşülen çiftçiler arasında okur-yazar olmayan kişilere rastlanmamıştır. Çiftçilerin medeni durumlarına bakıldığında \%78'inin evli, \%22'sinin bekar olduğu gözlemlenmiştir (Şekil 3).

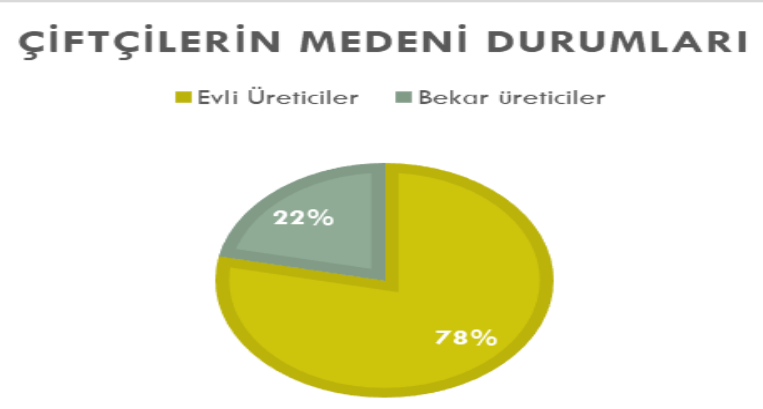

Şekil 3. Çiftçilerin medeni durumları 


\section{Çiftçilerin sosyo-ekonomik özellikleri}

Çiftçilere "düzenli bir geliriniz var mı?" şeklinde sorulan soruya çiftçilerin verdikleri yanıtlara bakıldığında \%17' sinin düzenli bir gelire sahip olduğu, \%83'ünün ise düzenli bir gelire sahip olmadığı ortaya çıkmaktadır. $\mathrm{Bu}$ bulgu aslında tarım ve hayvancılık yapan çiftçilerin önemli bir kısmının girdi ve çıktılar ile ileriye dönük planlamalar açısından rasyonel ve öngörülebilir bir durumda olmadıkları anlamını işaret etmektedir.

\section{Çiftçilerin tarımsal faaliyetleri}

Çiftçilere "kaç yıldır tarımla uğraşıyorsunuz?" şeklinde sorulan soruya çiftçilerin verdiği yanıtlara bakıldığında $\% 3 ’ u ̈ 40$ yıl ve üzeri, \%10’u 11-20 yıl, \%15'i 1-10 y1l, \%35'i 21-30 y1l ve son olarak ta \%37'si 31-40 yıl arasında olduğu Şekil 4' te görülmektedir.

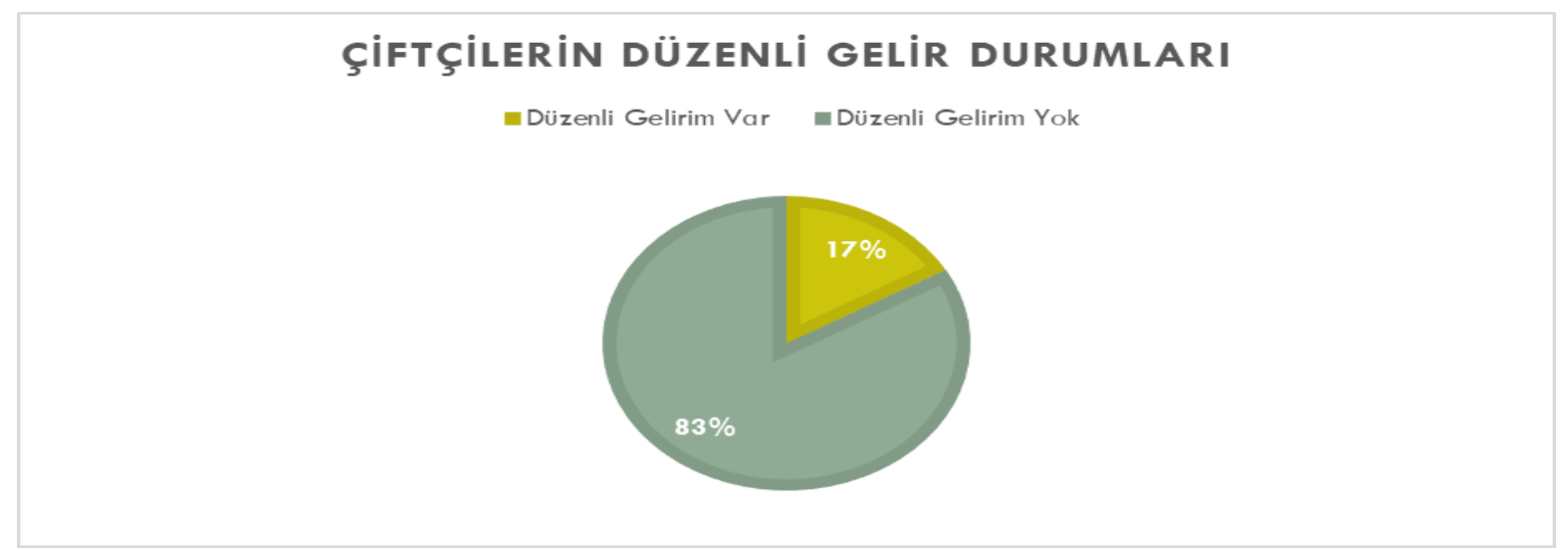

Şekil 4. Katılımcıların düzenli gelirlerine göre dağılımı

Çiftçilere "düzenli bir geliriniz var mı?" şeklinde sorulan soruya çiftçilerin verdikleri yanıtlara bakıldığında \%17' sinin düzenli bir gelire sahip olduğu, \%83'ünün ise düzenli bir gelire sahip olmadığı ortaya çıkmaktadır. Bu bulgu aslında tarım ve hayvancılık yapan çiftçilerin önemli bir kısmının girdi ve çıktılar ile ileriye dönük planlamalar açısından rasyonel ve öngörülebilir bir durumda olmadıkları anlamını işaret etmektedir.

\section{Çiftçilerin Tarımsal Faaliyetleri}

Çiftçilere "kaç yıldır tarımla uğraşıyorsunuz?" şeklinde sorulan soruya çiftçilerin verdiği yanıtlara bakıldığında \%3’ü 40 yıl ve üzeri, \%10'u 11-20 yıl, \%15'i 1-10 y1l, \%35'i 21-30 y1l ve son olarak da \%37'si 31-40 yıl arasında olduğu Şekil 5'te görülmektedir. 


\section{ÇIFTÇILERIN TARIMLA UĞRAŞTIKLARI YIL ARALIĞI}

-1 -10 yıl arası $\square$ 11-20 yıl arası $\quad$ 21-30 yıl arası $\quad$ 31-40 yıl arası $\quad 40$ yıl üzeri

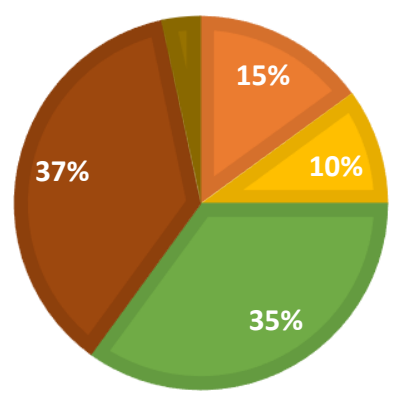

Şekil 5. Katılımcıların tarımla uğraştıkları yıllara göre dağılımı

Buradan anlaşılacağı gibi çiftçilerin en belirgin ekonomik kaynaklarını ürettikleri ürünlerden elde ettikleri söylenebilir ayrıca tarımla uğraşan grupların çok uzun bir geçmişe dayalı olması, tarım zemininin sağlam bir yapıya sahip olduğunu göstermektedir. Çiftçiliğin dünyanın en eski mesleklerinden biri olması nedeniyle, tarımsal üretimde ve doğal varlıkların korunmasında sürdürülebilirliğin ve kırsal kalkınmanın etkin bir parçası olma özelliği de vardır. Çiftçilik tarımın yapı taşlarındandır. Bu ülkemiz için de böyledir, dünya için de. Çiftçilik hangi düzey ve koşulda olursa olsun gerçek bir üretim faaliyetidir, hayata tutunma yolu ve iş kapısıdır. Çiftçilere, "çiftçilik yapmaktan memnun musunuz ?" sorusu sorulmuş ve verilen cevaplar Şekil 6'da görülmektedir.

\section{ÇIFTÇiLIK YAPMAKTAN MEMNUN MUSUNUZ?}

- Memnunum

Kısmen Memnunum

— Memnun Değilim

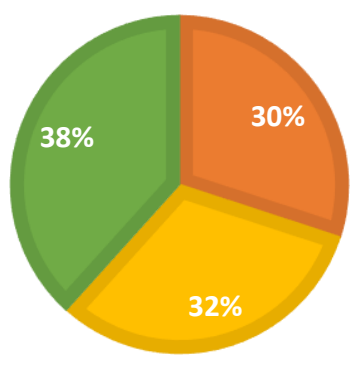

Şekil 6. Katılımcıların çiftçilikten memnuniyetlerine göre dağılımı 
Çiftçilerin \%30’u “memnunum”, \%32'si "k1smen memnunum" ve \% 38'i ise "memnun değilim" cevabını vermiştir. Oranların birbirine yakın olması eşite yakın bir dağılım göstermektedir. \%38 (memnun değilim) oranı ele alındığında çiftçilerin bu mesleği bulundukları konum, aile mesleği vb. koşullar nedeniyle yaptıkları söylenebilir. Yem bitkisi üretimi yapan çiftçilere ekim nedeni sorulmuş ve alınan cevaplar Şekil 7' de görülmektedir.

\section{ÇIFTÇiLERIN YEM BITKISI EKIM NEDENLERi}

- Zorunlu Olduğu İçin Ekiyorum

- Münavebede Kolaylık Sağladığı Için Ekiyorum

- Hayvancılıkla Uğraştığım İçin Ekiyorum

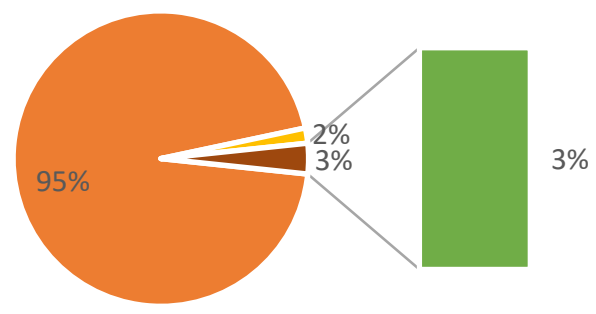

Şekil 7. Katılımcıların yem bitkisi ekim nedenleri göre dağılımı

Çiftçilerin \%95' i yem bitkisi ekimini zorunlu olduğu için, \%2'lik k1smının münavebede kolaylık sağladığı için, \%3' ünün ise hayvanları için ekim yaptıkları gözlenmiştir. Burdan hareketle katılımcıların hayvancılıkla uğraşma oranlarının az olduğu söylenebilir. Çiftçilerin "yem bitkisi desteği artarsa ekim alanları da artar “ görüşüne ilişkin dağılımları Şekil 8' de görülmektedir. 


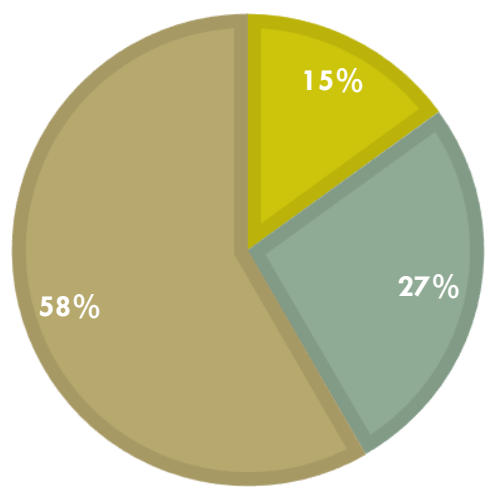

Şekil 8. Yem bitkisi desteği artarsa ekim alanları da artar

Katılımcıların \%58' i yem desteği artsa bile ekim alanlarının artmayacağını düşünmektedir. Üreticilerin çoğunluğu yem bitkisinden elde edilen gelirin düşük olduğunu ve bunun kendilerine yeterli bir kazanç olmayacağını söylemiştir. Yem bitkisini yetiştiren çiftçi; yetiştirdiği yem bitkisini kendi hayvanına yedirmesi ile elde edeceği ek hayvansal ürün gelirinin veya yem bitkisini pazarladığında elde edeceği gelirin, yem bitkisi yetiştirdiği tarlada başka bir alternatif bitkiyi ürettiğinde elde edeceği gelirden fazla olması gerektiğini düşünmektedir. $\mathrm{Bu}$ koşulun sağlanmadığ1 durumlarda üreticinin yem bitkisi üretmeye istekli olması olanaksızdır. Bu koşulun sağlanması için; hayvancılığın karlı bir faaliyet alanı haline dönüştürülmesi gerekir.
Katılımcıların \%27’si “kısmen kat1lyorum" ve kalan \%15'i ise "katılıyorum" diyerek yem desteğinin artması durumunda ilginin ve yem bitkisi ekim alanlarının daha da artacağını düşünmektedir. Dünyada ve ülkemizde geniş yer tutan çayır-mera alanları yaban hayvanları için bir barınma alanı, kirli havayı temizlediğinden ekosistemin önemli bir ögesi, biyolojik çeşitlilik ile birçok bitki ve hayvan türüne ev sahipliği yapmaları, arıcılık için doğrudan üretim alanı olmaları, erozyona engel olarak topraklarımızı korumaları gibi insanoğluna birçok alanda katk1 sunmaktadır. Üreticinin yaşadığ 1 yerdeki mera varlığı yem bitkisi üretimini doğrudan etkiler görüşüne ilişkin dağılımlar Şekil 9'da görülmektedir. 


\section{MERA VARLIĞI YEM BITKISI ÜRETIMINI DOĞRUDAN ETKILER Mi? \\ Katılıyorum Kısmen Katılıyorum Katılmıyorum}

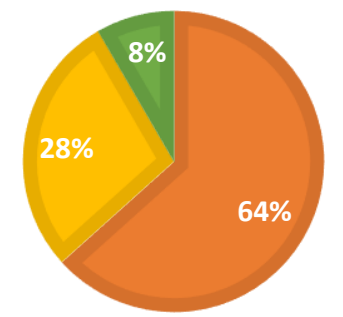

Şekil 9. Mera varlığı yem bitkisi üretimini doğrudan etkiler

Üreticilerin \%64' ü katılıyorum, \%28' i ise kısmen katılıyorum cevabını vererek mera varlığının yem bitkisi üretimini doğrudan etkilediğini savunmakta ve mera alanlarının artırılmasını istemektedir. Katılımcılardan $\% 8$ 'lik bölümü ise meranın bir etkisi olmadığını söylemiştir.

\section{TÜRKIYE'DE YEM BITKISI ÜRETICILERININ GELIR DÜZEYI YÜKSEK MIDIR?}

Katılıyorum Yüksektir Kısmen Katılıyorum Katılmıyorum Yüksek Değildir

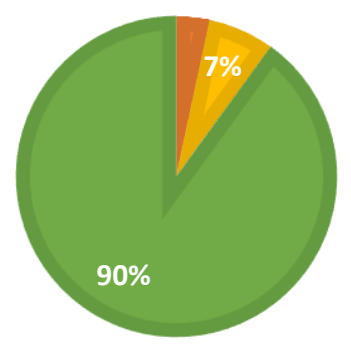

Şekil 10. Türkiye’ de yem bitkisi üreticilerinin gelir düzeyi yüksektir

Katılımcıların \%90' 1 Türkiye' deki yem bitkisi üreticilerinin gelir düzeyini yüksek bulmamakta, \%7'si bu duruma kısmen katılmakta ve $\% 3$ 'ü ise geliri yüksek bulduğunu ifade etmiştir. Üreticilerin yem bitkilerini konu alan eğitimlere katılıp katılmadığına dair dağılımlar Şekil 10’ da görülmektedir. Katılımcıların, “yem bitkisi 
üreticilerin gelir düzeyi yüksektir” görüşüne ilişkin dağılımlar Şekil 3.3.6.' da görülmektedir. Katılımcıların \%95 oranla büyük kısmı eğitimlere katılmadıkları söylemişler ve sebep olarak ise eğitimlerden habersiz olduklarını ve bir kısmı ise bu eğitimlerle ilgilenmediğini belirtmiştir. Katılımcıların \%5' i eğitimlere katıldıklarını hatta bu eğitimlerin daha da artırılması gerektiğini söylemiştir. Yem bitkileri ve bunların üretim teknikleri konusunda çiftçilerimizin bilgileri yetersizdir. Yetiştirme tekniğinin yeterli düzeyde bilinmemesi, mevcut bilgilerin üreticiye sağlıklı aktarılamaması, tohum üretimi için gerekli alet ve ekipmanın yetersiz olması önemli bir sorundur. Her yöre çiftçisine ekolojik koşullara uygun yem bitkileri tarımı öğretilmeli, bu amaçla eldeki tarımsal yayım araçlarından en üst düzeyde yararlanılmalıdır. Ülkemizde yem bitkileri tarımının geliştirilebilmesi için, yem bitkileri tarımı ile ilgili eğitim sorununun da çözülmesi gerekir. Her şeyden önce, bakanlık bünyesinde bu konuda uzmanlaşmış eleman sayısı artırılmalıdır. Konusunda uzman teknik elemanlar, yetiştiricilerin işlerinin daha az yoğun olduğu kış döneminde çiftçileri yem bitkileri yetiştirme ve değerlendirme konularında düzenlenecek kurslarla eğitmelidir. Çiftçilerin hayvancılıkla uğraştığına ilişkin dağılımlar Şekil 11' de görülmektedir.

\section{HAYVANCILIKLA UĞRAŞIYOR MUSUNUZ?}

\section{— Uğraşıyorum —ğraşmıyorum}

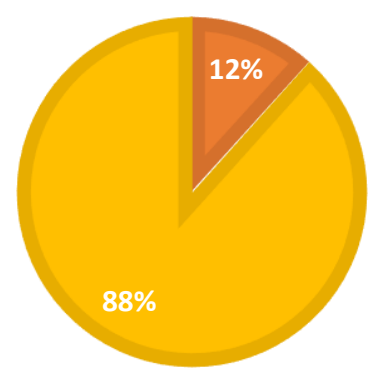

Şekil 11. Çiftçilerin hayvancılık faaliyetiyle uğraşmalarına göre dağı̆lımı 
Katılımcıların \%12' si hayvancılıkla ve yeterli vakitlerinin olmadığını uğraştığını belirtmiştir ve yem bitkisi belirtmişlerdir. Katılımcıların "yem üretimini bu nedenle yaptığını söylemiştir. bitkileri üretiminde teknoloji kullanımına \%88'i ise hayvancılık faaliyetiyle gerek var mıdır?” sorusuna ilişkin uğraşmadığını ifade etmiştir. Bunun nedeni düşünceleri Şekil 12'de görülmektedir.

sorulduğunda ise ekonomik bulmadıklarını

\section{YEM BITKISI ÜRETIMINDE TEKNOLOJI KULLANIMINA GEREK VAR MIDIR?}

Katılıyorum Gerek Vardır Kısmen katılıyorum $\quad$ Katılmıyorum Gerek Yoktur

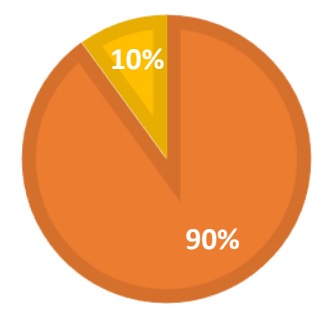

Şekil 12. Yem bitkisi üretiminde teknoloji kullanımına gerek var mıdır?

Katılımcıların \%90’ 1 katılıyorum cevabını vererek yem bitkisi üretiminde teknoloji kullanımına gerek olduğunu ifade etmiştir. Çiftçilerin \% 10’ u ise kısmen katıldığını söylemiştir. Çiftçiler yem bitkisi ekim işlemlerini genellikle mibzer, kültivatör, pulluk ve merdane ile gerçekleștirdiklerini ifade etmişlerdir. Katılımcıların "yem bitkisi üretimi ile hayvancılık doğru orantılıdır” görüşüne ilişkin dağılımlar Şekil 13' te görülmektedir. 


\section{YEM BITTKISI ÜRETIMI ILE HAYVANCILIK DOĞRU ORANTILI MIDIR?}

- Katılıyorum Doğru Orantılıdır Kısmen katılıyorum $\quad$ Katılmıyorum Doğru Orantılı Değildir

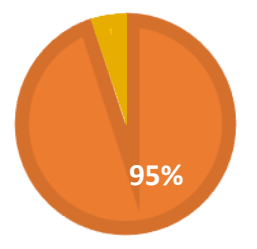

Şekil 13. Yem bitkisi üretimi ile hayvancılık doğru orantılıdır

Katılımcıların \%95' i katılıyorum , \%5' i Çiftçilerin yem bitkisi desteğinden kısmen katılıyorum cevabını vermiştir. faydalanma durumlarının dağılımı Şekil 14' Soruya katılmıyorum cevabı alınmamıştır. te görülmektedir.

\section{YEM BITKISI DESTEĞINDEN FAYDALANIYOR MUSUNUZ?}

- Faydalanıyorum Faydalanmıyorum

Şekil 14. Katılımcıların yem bitkisi desteğinden faydalanma durumları

Çiftçilerin tamamı yem bitkisi devlet desteğinden faydalanmaktadır. Çiftçiler hasat sonrası beş ay boş kalan tarlalarında, devletten destek alarak yem ekip satmaktadır. Tarım ve Orman Bakanlığ tarafindan 2018 yılında hayata geçirilen proje ile "3 y1l üst üste arazisine aynı ürünü eken çiftçi, destekleme alamayacak” kararı gereğince çiftçiler yem bitkisi ekimi yapmıştır. Katılımcıların yem bitkisi desteklerine olan memnuniyetlerini gösteren dağılım Şekil 15'te görülmektedir. 


\section{YEM BITKKISI DESTEKLERINDEN MEMNUN MUSUNUZ?}

Evet memnunum

Kısmen memnunum

- Hayır memnun değilim

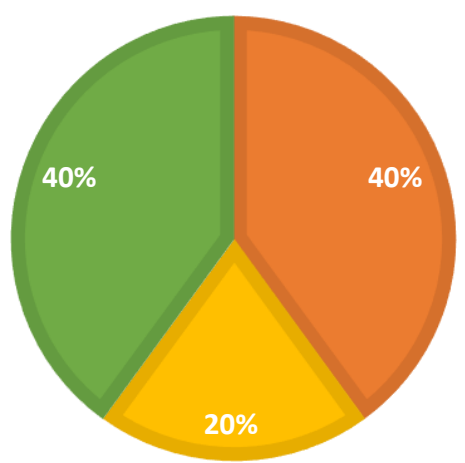

Şekil 15. Katılımcıların yem bitkisi desteklerine olan memnuniyetleri

Katılımcıların \%40’ı memnun olmadığını, \%20’ si kısmen memnun olduğunu ve kalan \%40' ise memnun olduklarını ifade etmiştir. Yem bitkisi üreticilerinin desteklemeler konusunda bilgilendirilmesi ve yem bitkisi üretiminde belirli bir düzeye gelene kadar desteklemelere devam edilmesi gereklidir. Çiftçilerin yem bitkisi üreticisi olmaktan memnun musun sorusuna ilişkin dağılımları Şekil 16'da görülmektedir.

\section{YEM BITKISI ÜRETICISI OLMAKTAN MEMNUN MUSUNUZ? \\ Memnunum $\square$ Kısmen Memnunum $\square$ Memnun Değilim}

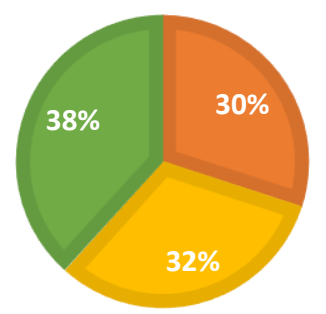

Şekil 16. Yem bitkisi üretici olmaktan memnun musun? 
Çiftçilerin \%38'i memnun değilken, \%32' si k1smen memnunum ve \%30' $\mathrm{u}$ ise memnunum cevabını vermiştir. Olumsuz cevap veren çiftçilere nedeni sorulduğunda bu üretimin kendileri için zaman kaybı olduğunu belirtmiş ve bu uygulamayı zorunlu olduğu için yaptıklarını belirtmiştir. Yaz yağışlarının görüldüğü ve yaz sıcaklıklarının düşük olduğu yerlerde pamuk üretimi yapılamamaktadır. Şanlıurfa GAP kapsamında sulamaya açılan Harran ve Suruç ovaları ile pamuk üretiminde önemli bir merkez haline gelmiştir. $\mathrm{Bu}$ nedenle Türkiye'de pamuk üretimi en çok Güneydoğu Anadolu Bölgesi'nde gerçekleştirilmektedir. 2017 yılında toplam pamuk üretiminin \%42'si Şanlıurfa'da yapılmıştır. Aydın, Hatay, Diyarbakır ve Adana'da yapılan pamuk üretiminin toplamı, yaklaşık olarak Şanlıurfa'daki üretim kadar olmuştur. Çiftçi, hasat sonrası 5 ay gibi bir süre boş kalan arazilerine ilk yıl devletten aldıkları tohum desteği ile yem bitkisi ekmiştir. Bu yıl Harran Ovası' nın yarısından fazlası yem bitkisi ekiminin yapıldığı alanlarda fiğ tercih edilmiştir. Fiğ yaklaşık 150 türü bulunan ve tek yıllık bir baklagil yem bitkisidir. $\mathrm{Bu}$ bitkinin anavatanı Akdeniz, Asya ve Avrupa ülkeleridir. Fiğ türlerinin ne zaman kültüre alındığı bilinmemektedir. Fiğin ülkemizde doğal olarak yetişen türleri vardır. Fĭg türleri geniş adaptasyon yeteneğine sahiptir. $\mathrm{Bu}$ nedenle Akdeniz ülkelerinde, Avrupa'nın orta ve kuzey bölgelerinde, Amerika Birleşik Devletlerinde ve Ortadoğu ülkelerinde yaygın olarak yetiştirilmektedir. Fĭğ, ot verimi yüksek olan ve elde edilen otunun besin değeri iyi olan bir baklagil yem bitkisidir. Fiğ türleri ülkemizde genellikle kaba yem elde etmek amacıyla yetiştirilmektedir. Fakat tohumları yüksek oranda protein içerdiği için kesif yem amacıyla da yetiştirilmektedir. Fĭg bitkisinden elde edilen ot hayvanlarda şişmeye neden olmaz. Çiçeklenme dönemi başlangıcında biçilen fĭg kuru otunda yaklaşık olarak \%12-20 ham protein, \%610 ham kül, \%25-26 ham selüloz ve \%4546 azotsuz öz madde bulunur. Ülkemizde yetiştirilen fiğ bitkisi yeşil veya kuru ot elde etmek, tane yem elde etmek, yeşil gübre bitkisi olarak, mera bitkisi olarak ve silajlık bitki olarak kullanılır. Fiğ yeşil gübre olarak kullanıldığında kütlü pamuk verimini artırmaktadır. Üretim maliyetinin düşürülmesi için, gereğinden fazla kullanılan bazı üretim girdilerinin optimum kullanımının sağlanması çok önemlidir. Pamuk tarımının en önemli girdilerinden biri kimyasal gübreler olup gereğinden fazla kullanılmaktadır. Bunun yanında 
pestisit, bitki gelişme düzenleyicileri ve diğer kimyasallar da yoğun olarak kullanılmaktadır. Bunların yoğun ve bilinçsizce kullanımı pamuk maliyetini artırdığı gibi doğal dengenin bozulmasına, toprakların fiziksel ve kimyasal yapısının değişmesine ve çevre kirlenmesine neden olmaktadır. Kimyasal yapısı bozulan toprakların ıslahı zor, maliyeti çok yüksek ve bazı hallerde ise mümkün olmamaktadır. Gübrenin pahalı bir girdi olması ve toprakların fiziksel ve kimyasal yapısında olumsuzluklar meydana getirmesi, gübrelerin çok dikkatli kullanılmasını ve organik gübreler ile desteklenmesini gerektirmektedir. Organik gübreler içinde pamuk tarımına en uygun ve en pratik olarak uygulanabilen yeşil gübre bitkisi fiğ'dir. Katılımcılara “yem bitkisi ekimi pamuk verimini artırır mı?” şeklinde soru yöneltilmiş ve alınan cevaplar Şekil 17'de görülmektedir.

\section{YEM BITKISI ÜRETIMI PAMUK VERIMINI ARTIRIR MI?}

- Katılıyorum Artırır Kısmen katılıyorum Katılmıyorum Artırmaz

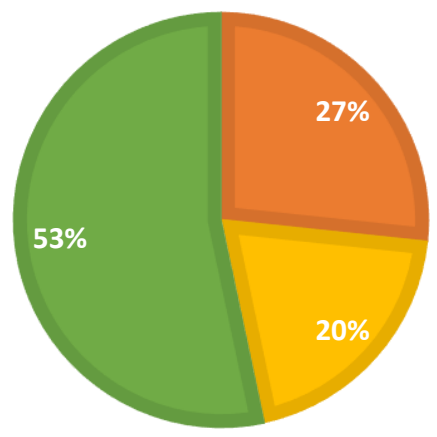

Şekil 17. "Yem bitkisi üretimi pamuk verimini arttırır mı ?" ifadeleri

Katılımcıların \%53' ü yem bitkisi ekiminin pamukta verimi artırmayacağını düşünürken, \%20' si kısmen katılmış ve kalan \%27' si ise katıldığını belirtmiştir. Çiftçilerin çoğunun yem bitkileri hakkında bilgi yetersizliği olduğu bu soruda net bir şekilde görülmüştür. Çiftçilere teşvik edici eğitimlerin artması ve bu eğitimlerin uygulanması gereklidir. Katılımcıların "yem bitkisi üretimini diğer çiftçilere de öneririm" e göre dağılımı Şekil 18'de görülmektedir. 


\section{YEM BiTKisi üRETIMINi DiĞER ÇiFTçiLERE ÖNERIRIM}

\section{Katılıyorum Öneririm Kısmen katılıyorum Katılmıyorum Önermem}

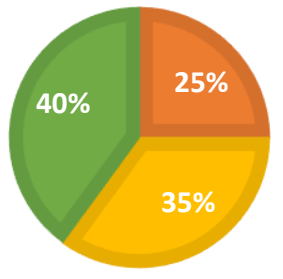

Şekil 18. Yem bitkisi üretimini diğer çiftçilere öneririm

Katılımc1ların \%25' i katılıyorum diyerek yem bitkisi ekimini diğer çiftçilere de önerebileceğini belirtirken, $\% \quad 40^{\prime} \quad 1$ katılmıyorum cevabını vererek önermeyeceğini ve kalan \%35' i ise kısmen katılıyorum diyerek kararsız olduğunu belirtmiştir. Çiftçiler neden önermeyecekleri sorusuna ise yem bitkisi pazar piyasasını yeterli bulmadığın ve verim düşüklüğü olduğunu söylemiştir. Katılımcılara yem bitkisi üretiminde yetersizliğin nedenleri sorulduğunda ve buna ilişkin görüşler Şekil 19'da görülmektedir.

\section{YEM BITKISI ÜRETIMINDE YETERSIZLIĞiN NEDENLERI}
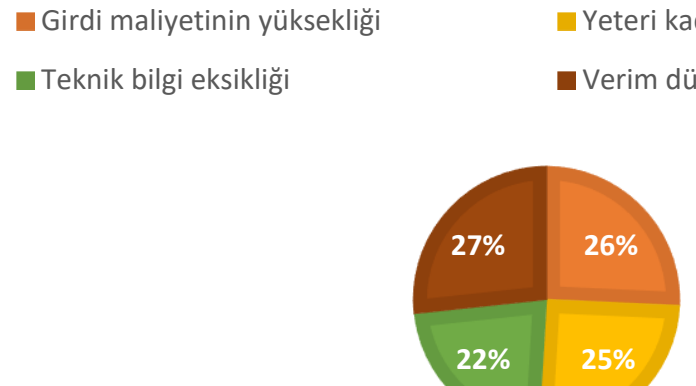

Şekil 19. Yem bitkisi üretiminde yetersizliğin nedenleri 
Çiftçiler bu soruda birden fazla yanıt kullanmıştır. 55 çiftçi verim düşüklüğünü, 53 çiftçi girdi fiyatlarını yüksek olmasını, 52 çiftçi yeteri kadar pazar piyasasının olmamasını ve 46 çiftçi ise teknik bilgi eksikliği olduğundan dolayı yem bitkisi üretiminde yetersiz olunduğunu belirtmiştir. Katılımcılara çiftçi olarak en önemli sorunları sorulmuş ve alınan yanıtlar Şekil 20’ de görülmektedir.

\section{ÇiFTÇiLERIN EN ÖNEMLI SORUNLARI}

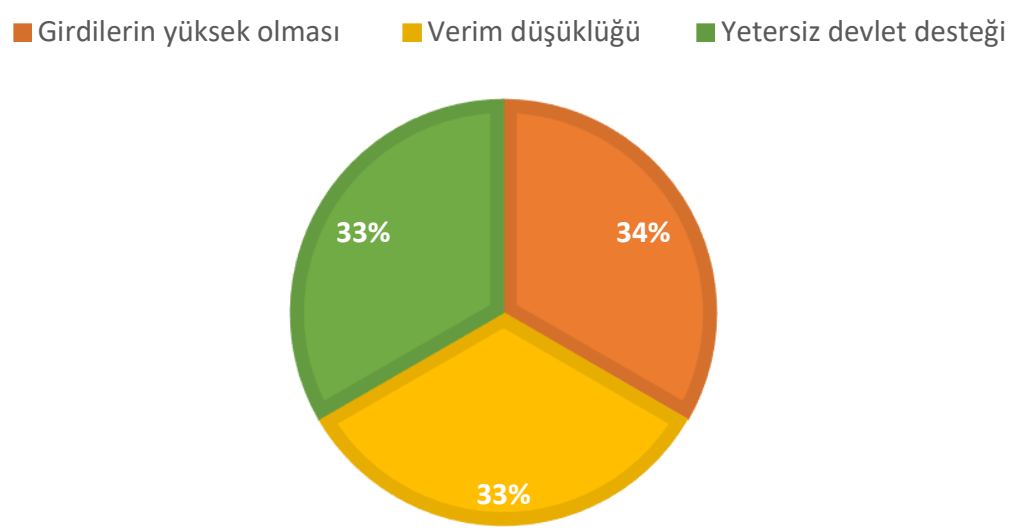

Şekil 20. Çiftçilerin en önemli sorunları

Çiftçilerin sorunlarına bakıldığında genel olarak üç cevap alınmıştır. Bunlar; girdilerin yüksek olması, verim düşüklüğü ve yetersiz devlet desteği olmuştur. Üretici olarak ise en önemli beklentilerinin devlet desteğinin artması yönündedir.

\section{SONUÇLAR ve ÖNERILLER}

\section{Sonuçlar}

Çalışmada yem bitkisi üreticilerinin sosyo-ekonomik özellikleri, yem bitkisi desteklemelerinin yem bitkisi üretimine etkisi ve yem bitkisi destekleme uygulamaları konusunda üreticileri görüşleri incelenerek destekleme politikalarının etkisi ölçülmeye çalışılmıştır. Yem bitkisi üretiminin artırılması için devlet desteğinin daha da artırılması gerektiği görülmüştür. Genel olarak üreticiler yem bitkilerini Tarım Bakanlığı' nın geliştirdiği proje kapsamında üretmektedir. Harran Ovası'nda yapılan çalışmada üreticilerin yem bitkisi tarımı ve yetiştiriciliği konusunda önemli bilgi eksikliklerinin olduğu gözlenmiştir. Harran Ovası'nda üreticilerin eğitim seviyesinin düşük olduğu, geleneksel tarıma dayalı 
yetiştiricilik yapmakta olduğu, tarımsal ürünlerin daha iyi değerlendirilmesi için işletme yapılarının iyileştirilmesi ve geliştirilmesi yönünde yeterli çabalarının olmadığı ve bu alanda eğitime önem verilmesi gerektiği saptanmıştır. Çalışma yapılan alandaki üreticilerin yem bitkileri yetiştiriciliği yaparken teknolojik tarım aletlerinden kısmen faydalandığı görülmektedir. Çiftçiler arasında hayvancılık faaliyetiyle uğraşan üretici sayısı az olmakla birlikte, yem bitkisi üretimi yapan çiftçilerden çok az bir kısmının bunu hayvanları için yaptığı saptanmıştır. Çiftçiler hayvancılık ve yem bitkisi üretimi arasında doğru bir orantı olduğunu düşünmektedir. Üreticiler genel olarak Türkiye' de yem bitkisi üreticilerinin gelirlerinin düşük olduğunu belirtmiştir.

\section{Öneriler}

Araştırma sonucunda yem bitkisi ekiminin yaygınlaşması için devlet desteğinin sürdürülebilir olması gerektiği gözlenmiştir. Çiftçilere yönelik tarımsal yayım ve iletişimin geliştirilmesi ve bu eğitimlerin arttırılması gerekmektedir. Üreticilerin eğitimlere katılması kısmen zorunlu hale getirilerek bilgi eksiklikleri bu yönde giderilebilir.

\section{KAYNAKÇA}

Ağırbaş, N.C., Sapmaz, K., Koç, A. 2016. Eskişehir ilinde yem bitkileri ekiliş alanı ve üretim miktarı üzerine tarımsal desteklemelerin etkisi. Atatürk Üniv. Ziraat Fak. Dergisi, 48 (1): 65-72.

Akman, K., Kara, B. 2007. Isparta yöresinde yetiştirilen arpa köy çeşitlerinin verim ve verim öğelerinin belirlenmesi. Akdeniz Üniversitesi Ziraat Fakültesi Dergisi, 20(2):163-169

Altıntaş, G., Altıntaş, A., Çakmak, 2017a. Yem bitkisi desteklerinin yem bitkisi üretimine etkisi (Sivas İli Örneği). Gaziosmanpaşa Üniversitesi Ziraat Fakültesi Dergisi, 34 (2): 116-127

Altıntaş, G., Altıntaş, A., Çakmak 2017b. Yem bitkileri üretiminde sürdürülebilirlik üzerine bir çalışma: Sivas İli Örneği. TEAD, 3(1): 38-51,

Alçiçek,, A., Kılıç, A., Ayhan, V., Özdoğan, M., 2010. Türkiye'de kaba yem üretimi ve sorunları. Türkiye' de Kaba Yem Üretimi ve Sorunları. http://zmo.org.tr/resimler/ekler/819fb9034f 79627_ek.pdf (Erişim Tarihi: 05.04.2020)

Anonim, 2020. Çiftçi Algısı Analizi. https://www.trakyaka.org.tr/upload/Node/3 3083/xfiles/Ciftci_Algisi_Analizi_Kantita tif_Rapor.pdf (Erişim Tarihi: 01.04.2020) 
Anonim, 2012. Fĭg bitkisi ile yeşil gübreleme pamukta verimi artırıyor. https://www.haberler.com/fig-bitkisi-ileyesil-gubreleme-pamukta-verimi-4070127haberi/ (Erişim Tarihi:0.04.2020)

Anonim, 2018a. Genç çiftçi profili araştırması: Van İli Örneği. https://www.daka.org.tr/panel/files/files/ya yinlar/genc_ciftci_raporu_2018.pdf (Erişim Tarihi: 08.04.2020)

Anonim, 2020. Şanlıurfa Tarımında Verim İki Kat Artt1. Haberurfa. https://www.haberler.com/sanliurfatariminda-verim-iki-kat-artti-12992585haberi/ (Erişim Tarihi: 17.03.2020)

Artan, P. 2019. Şanliurfa sulu koşullarında bazı çok yıllık mevsim buğdaygil yem bitkisi türleriyle yoncanın saf ve karışık ekimlerinde yem kalite değerlerinin belirlenmesi.http://veteriner.h arran.edu.tr/assets/uploads/sites/53/files/2 019-1-15-17072019.pdf(Erişim Tarihi: 01.04.2020)

Balabanlı, C., Cirit, Y., Kayacan, S., Bıçakçı, E., Yüksel, O., 2016b. Yem bitkileri tarımında üretici davranışlarının belirlenmesi: Isparta İli Örneği. http://static.dergipark.org.tr/articledownloa d/fd62/de40/2173/587527f2dca3e.pdf?

(Erişim tarihi: 19.03.2020)
Demirtaş, Ş. 2015. Kışlık fiğ üretimi sonrası pamuk (Gossypium hirsutum L.) tarımı için uygulanan farklı toprak işleme sistemlerinin karşıllaştırılması. https://dergipark.org.tr/tr/download/articlefile/445242 (Erişim Tarihi: 16.04.2020)

Gülçubuk, B. 2018. Dünyanın en eski mesleklerinden ve en itibarlı işi: çiftçilik. Tarım ve Orman Dergisi. http://www.turktarim.gov.tr/Haber/80/duny anin-en-eski-mesleklerinden-ve-en-itibarliisi-ciftcilik (Erişim Tarihi: 16.04.2020

Karadavut, U., Genç, A., Palta, Ç., Çarkac1, A. ve Kökten, K., 2011. Konya ili yem bitkileri üreticilerinin sosyo-ekonomik yapıları ile başarılı üretimi etkileyen faktörlerin belirlenmesi. http://www.bingol.edu.tr/documents/7-Kon ya\%20Sosyo-ekonomik.pdf (Erişim Tarihi: 19.03.2020)

Kir, B., Soya, H. 2008a. Kimi mera tipi yonca çeşitlerinin bazı verim ve kalite özellikleri üzerinde bir araştırma. https://dergipark.org.tr/en/download/article -file/59274 (Erişim Tarihi: 19.04.2020)

Kızılaslan, Ü. 2013. Çiftçilerin Tarımsal Yayım Farkındalıklarının Belirlenmesi (Tokat/Erbaa Örneği). https://d ergipark.org.tr/tr/download/article-file/ 311603 (Erişim Tarihi: 01.04.2020) 
Sabanc1, C., Baytekin, H., Balabanl1, C., Acar, Z., 2008b. Yem bitkileri üretiminin artırılmasi olanakları. https://zmo.org.tr/resimler/ekler/7e77c835a f3d2a8_ek.pdf (Erişim Tarihi: 17.04.2020)

Serin, Y., Tan, M., 2001. Baklagil Yem

Bitkileri. Atatürk Üniversitesi Ziraat Fakültesi Yayınları, No: 190, 177 s.

Soya, H., R. Avcioğlu, H. Geren. 2004. Yem Bitkileri. Hasad Yayıncılık, 223 s.
Yildı, C. 2020. Ekim Nöbeti (Münavebe) Konulu Araştırma Çalışması. http://www.tarimkutuphanesi.com/amp/eki m_nobeti_(munavebe)_celal_yildiz_ziraa t_muhendisi_01566.html (Erişim Tarihi: 08.04.2020)

Yolcu, H., Tan, M. 2007. Organik Yem Yetiştiriciliği. Atatürk Üniv. Ziraat Fak. Derg.39 (1): 145-150. 